\title{
PHYSIOGNOMY OF THE OPERATIONS AGAINST TERRORISM
}

\author{
Mihai Marcel NEAG \\ “Nicolae Bălcescu" Land Forces Academy, Sibiu, Romania \\ mmneag@yahoo.com
}

\begin{abstract}
In current conflicts, the terrorist networks already represent a major player and the terrorist threats remain highly topical. In the physiognomy of the actions of the forces engaged in counter-terrorism operations offfensive actions must prevail, but there will be situations in which the military forces will have to undertake defensive actions aswell, because the neutralization of the terrorist entities does not necessarily mean removal of their infrastructure. The operations against terrorism require, for the military structures present in theaters, the review and reconsideration of their own tasks, forms and methods of action, profound transformation of the adopted strategies, a multi-dimensional vision on the effects to be achieved, a comprehensive approach to planning operations, that will help the management of the situations and achievement of the desired end state..
\end{abstract}

\section{Keywords: terorrism, insurgency, comprehensive approach, stability}

\section{Introduction}

Model of the war against terrorism reflects the fact that the way of carrying it is in a constant evolution. The threat of the terrorist networks and the states that support them, remains a universal feature of armed conflicts and future military operations. The war on terror establishes a new generation of war in which the military counter-terrorism operations have a special status due to considerable changes in how they are perceived and addressed.These operations are of a special type and are not like the offensive or defensive operations of a usual war only to a small extent and they do not resemble with special operations either. (Balint Mario, 2015)

The terrorist networks use the method of indirect action, avoids attacking strong military points of the democratic countries and employs the weak points and nonmilitary targets (FM 3-24, 2006). While the terrorists will try to attack less secured targets and installations in order to produce fear, panic, and to weaken confidence of civilians and politicians in their level of security, the general strategy of the actions will be aimed at weakening international public support given to the military or security force and for separating the local population from the armed forces.

It is very clear the fact that many active terrorist armed groups that continue to emerge on the political scene, will be a challenge to the way in which the military forces carry on their operations and on the physiognomy of counterterrorism operations. At the same time, the terrorist actions aimed at achieving specific policy goals, acting on some individual and / or collective human entities and goods, to produce effects with a strong psychological impact on the population and public opinion.

The force structures involved in the fight against terrorism must take into account that acts of this kind are committed with premeditation, are the result of beliefs and attitudes hostile to various institutions and social groups, that terrorists practice violent 
and destructive ways of expressing the desire to impose values they believe in. We must also take into consideration the fact that in order to combat terrorism the military structures execute specific tasks under the circumstances in which in the theater of operations is usually carried out an ample movement of insurgency, a type of reaction that aims at depriving of legitimacy the existing government and gaining political power by using in an organized way, direct armed actions.

The military operations to combat terrorism and counterinsurgency have in common the fact that it requires effective cooperation of the military structures, international organizations, government and nongovernment agencies as well as that they finally aim to obtain or regain the legitimacy of the government of the host nation, because it can provide essential services for the population, the elimination of the causes that led to the terrorist and insurgent movement and the prevention of other crises and similar phenomena.

\section{Characteristics of the military operations against terrorism}

Viewed from the perspective of the overall missions of the military organism, the participation in the fight against terrorism is part of the national security missions. The military operations to combat terrorism, as part of the stabilization mission, involve the use of forms and methods of action carried out in coordination with the instruments of power of the host nation, to create conditions for the reconstruction of essential infrastructure elements and humanitarian aid. These tasks force the military structures to adopt a comprehensive approach in the conduct of operations.

One such approach to the structures of the military force an integrating design is required regarding the use of civilian and military instruments to generate the desired effects. Likewise, the structures of the military forces need command and control capabilities, providing informational support, mobility and employment of the opponent, of support, insurance and protection as well as the influence of the perception, attitudes and behaviors, assistance for the post-conflict reconstruction.

In terms of their physiognomy the main feature of the military operations to combat terrorism is that actions are carried out, where appropriate, in areas under government control of the host nation and / or areas where control is virtually nonexistent, it largely belonging to terrorist and / or insurgent entities.

In the first situation, to ensure the public security, the military operations target to restore / regain or maintain control of the territory, in order to restore essential services and resume normal social life. In the second situation, a more complex one, the first objective should be to identify and support the elements that could lead to the stabilization of the area politically. In both situations, the military operations against terrorism may be carried out in the presence or absence of insurgency movements.

Another feature of the physiognomy of these operations is the staging of the operations. If the military action specific to the classical meaning includes a preparatory step, the the decisive step and the stabilizing step, in the fight against terrorism, the military action is carried out in three stages, as follows: the immediate reaction stage; the stabilization stage; the transfer of authority stage. Within these stages neutralization, security and reconstruction missions are run when offensive, defense and stability type operations are combined in different proportions. The offensive type operations are primarily aimed at discoving and eliminating terrorist entities, the defensive ones aim at protecting the local population and the stabilityoperations, at rebuilding infrastructures, restoring the legitimacy of local government, the establishment of law and order in the area of operations. (Fig.1) 

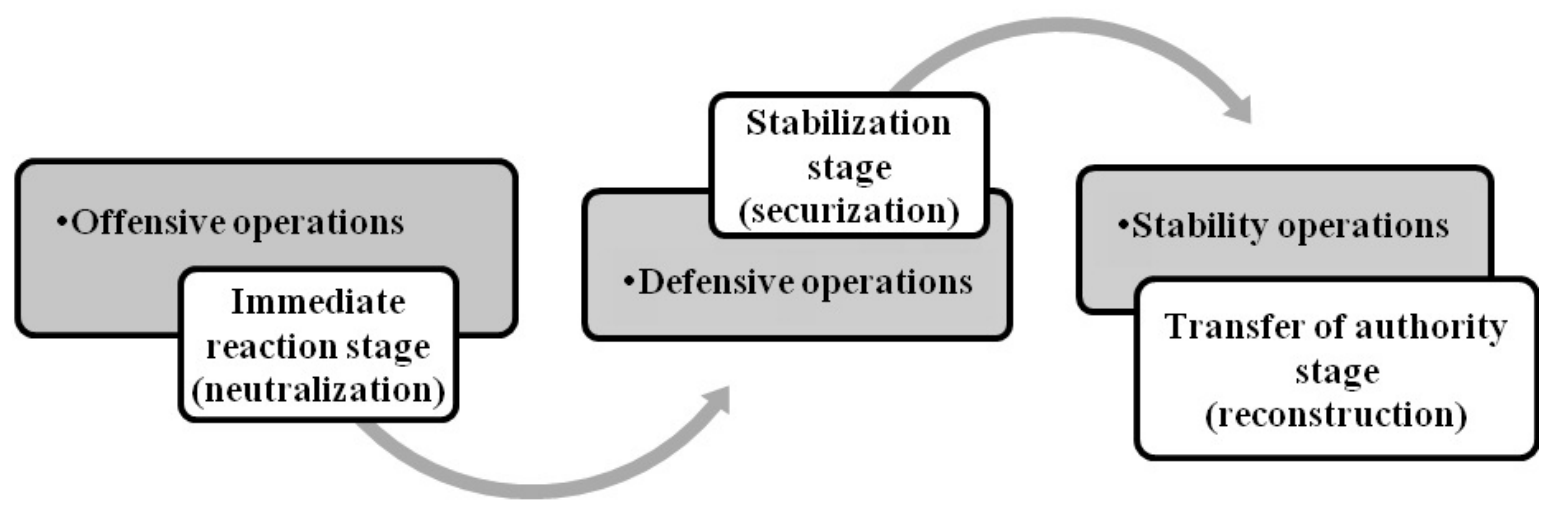

Figure 1: The stages of the military actions and the proportion of military operations

Immediate reaction stage.The operations within this stage must start with actions to take control of the area and to complete the creation of a secure operating environment, through actions to combat terrorism, elimination from the fight of the terrorists and support of the civilian population against terrorist actions. Within this stage, the military forces carry out offensive type missions mainly. The main tasks to be fulfilled at this stage are neutralizing actions to eliminate the terrorist forces and their resilience in the area entrusted, by annihilation, capturing terrorists or by forcing them to withdraw from the area. The action methods to accomplish these missions are searching, patrolling, ambushing or executing raids on the terrorists' important targets.

Preparing military operation at this stage should consider the identification of the necessary means to strengthen the neutralization of the terrorist entities within the entrusted area, the elements to coordinate actions for the collection and dissemination of data and information and the cooperation with other forces in the area of responsibility. The carrying out of the operation involves engaging the forces over a long period of time and ensuring the unity of effort between the multinational forces, civilian authorities, security forces of the host nation and agencies involved in the stabilization process.
Specific to this stage is to maintain the advantage obtained against terrorist structures and create the conditions necessary to conduct future attacks. These missions can be accomplished through defensive and stability operations, to isolate the area, block the external support for terrorist entities, neutralize or capture the terrorists trying to leave the area, enforce patrols to identify and eliminate terrorist elements and to ensure the population's security, deployment of the security forces throughout the area to ensure public safety and to facilitate the transition to the next stages of the mission.

Stabilization phase.At this stage, after ensuring the security of civilians, the final of the first stage, the focus must be on postconflict reconstruction actions, the stabilization and reconstruction of the capabilities of the security forces, ensuring of the essential services and stabilization of the relations between the host nation government and the security forces on one hand and the civilian population, on the other one. At this stage, the structures participating in operations to combat terrorism, could perform, as appropriate, striking actions to neutralize the terrorist entities, that might help the civilian population and resource protection against the action of terrorist entities that should complement the security efforts of the first stage. At the same time the forces engaged 
in counter-terrorism operations must forbit any possible retaliation of the terrorist entities by occupying forward operations bases in key locations in their area of responsibility, secure the infrastructure elements vital to the stability in the area.

This stage focuses, in particular, on defensive operations. The military structures may be involved in the stabilization phase, to support the management and administrative structures at the local level. The actions aimed at restoring the essential services for the population, economic development and infrastructures support through measures and actions meant to involve local population in the reconstruction effort. Depending on the operational capabilities and logistics sustainability, at the tactical level, the host nation security forces should act to ensure public safety and continuity of the local government.

Having in view the experience of the military actions carried out to combat terrorism, effectiveness maintaining of the secure areas resulted, by establishing bases within or in the proximity, out of which the forces engaged in combating terrorist entities can focus their actions to identify and eliminate them, mainly having as priority targets the leaders and the infrastructure of their organizations, and by limiting or even eliminating terrorist support of the local population and winning its support for the authority of the legally constituted government.

Transfer of authority stage. This stage has as a political-military aim, to restore in the long run, the capabilities and create conditions for economic and social development. The strengthening of the institutions of the governmental authority, the progress in establishing a climate of law and order do not exclude a future ensuring of the protection of the population.

At a military level, at this stage the stability operations predominate versus the offensive and defensive ones, with the support, if possible, of the host nation' security
forces.The force structures of a tactical level must carry out permanent patrol service, and if it requires dealing with terrorist or insurgent elements, they must be able to switch to the proportional use of force. If the host nation' security forces are insufficient, within the cooperation with the government and local authorities of the host nation, the employment and training of local paramilitary forces should be considered, to ensure security of settlements and surrounding areas.

At this stage, the transfer of responsibility to combat terrorism and insurgency should be done gradually towards the security forces and the political and military leadership of the host nation. The role of the multinational military forces is to support the host nation' forces, both by combat actions but also by maintaining, as far as necessary, the fire support capabilities.

An important objective is, at this phase of operations, the continuing actions to destroy the infrastructure elements of the terrorist entities remained unaffected, because they will continue to pose a threat and will affect the local people's attitude to the mission of the multinational forces.

Simultaneously, within the reconstruction process, the government of the host nation must take measures to restore the functioning of the government institutions and restore viable administrative procedures, and the agencies of national and international development should rebuild the infrastructure necessary for a normal social and economic life, a process in which finding, training and vesting with authority of local leaders is very important.

\section{Comprehensive approach to the actions of combating terrorism}

The contemporary terrorism is a major threat to the stability of the international security system at a multidimensional level. Although the terrorists justify their actions by the fight for liberation from the developed countries'influence, which have 
certain interests in the region or against the totalitarian regimes, the used means, infliction of loses among the civilian population in order to influence the governmental authorities to adopt certain measures, does not justify reaching these purposes and does not exclude, under any circumstances, the terrorist character of the actions.

The objectives of the terrorist actions include "attacks on symbols, monuments, cemeteries, major buildings, bridges, architectural works etc., in an attempt to show the world that there is a force above states, armies, parties, institutions and existing order, that will punish those who do not believe in it, causing virulent reactions of the authorities, so as they can be charged and thus attract, to their side, the public opinion, causing panic and insecurity." (Center for strategic studies, Bucharest, 2002, p. 73). The diversity of the terrorist actions requires a comprehensive approach to combating terrorism.

Fighting against or countering terrorism is a generic term used to describe all terrorism and counterterrorism measures. To achieve the necessary conditions for success against a terrorist threat one must pass the traditional barrier of an exclusive application of a lethal force by integrating the full range of actions / capabilities that are to generate an adequate combat power against the threat and the specific situation of ongoing confrontation such as: information operations, electronic attack, psychological operations, civil and public relations activities. The fact that many citizens of the planet live in areas with a high potential conflict risk, in poverty, with political, ethnic, religious, territorial disputes, in states that do not have a monopoly of power or with totalitarian regimes, should not justify the support of the terrorists. The terrorists speculate dramatic realities, distorted perceptions and frustrations in order to implement their insidious and harmful aims. (Col. Constantin-Valentin BORDEI, PhD, 2015)
Within the comprehensive approach of the operations against terrorism measures to ensure the security of civilians are taken into consideration, by the presence and control exercised by the government forces in the area of operations and on the population, activate the local paramilitary forces and their integration in operations, train and support of the police forces, fight against crime and strengthen the law enforcement.

The success of the counter-terrorism operations may be favored by the continuous contact at various levels between the military structures and the population in the area of operations. Such opportunities, to establish contacts and exchange information with people, can be easier if the military base is located in the middle of the local population or as close as possible to it. Creating the connection between the military and the local population can be achieved from the first days of the forces' presence in the area, by deep knowledge and respect of the traditions and local customs by the military. The contacts with the civilian population are required to obtain a more realistic picture of the situation and obtain support of the locals for the government authorities. The quality of these relationships depends upon the observance of the principles governing the civil-military relations (knowing and respecting the cultural identity of the local population, identifying the common goals and shared responsibility, consensus in dealing with governmental, nongovernmental and private volunteer ones, transparency and effective communication with public authorities, international organizations, NGOs and civilians).

However, a comprehensive approach to the operations against terrorism requires certain features of their planning process, in that it requires the development of optimum integrated operations plans within the overall plan of operations for the stabilization of the conflict area, to 
concentrate efforts in the long, medium and short run, taking into account that, as a rule, during these operations the expected effects are slow and can be measured with difficulty. Planning and carrying out the counter-terrorism operations take place in a multidimensional environment, which are peculiar to surprising challenges typical to stability operations. We should also consider the fact that without careful preparation, with strong prospective meanings in terms of information of the area of operations, to facilitate a multidimensional understanding of the operational environment, technical and doctrinal strengths of the military forces can easily be countered by the suppleness, flexibility and lack of moral guidelines of the actions of terrorist entities. This approach imposes on the force structures to use a wide range of means, to cooperate with different actors and to effectively combine different political, civilian and military actions to achieve these objectives and generate defining effects for the desired end state.

In the combat terrorism operations, to generate cumulative effects, the capabilities of the military structures must be supported properly, through a good coordination with the central and local authorities of the host nation and the international governmental and nongovernmental organizations and agencies located in the conflict zone.

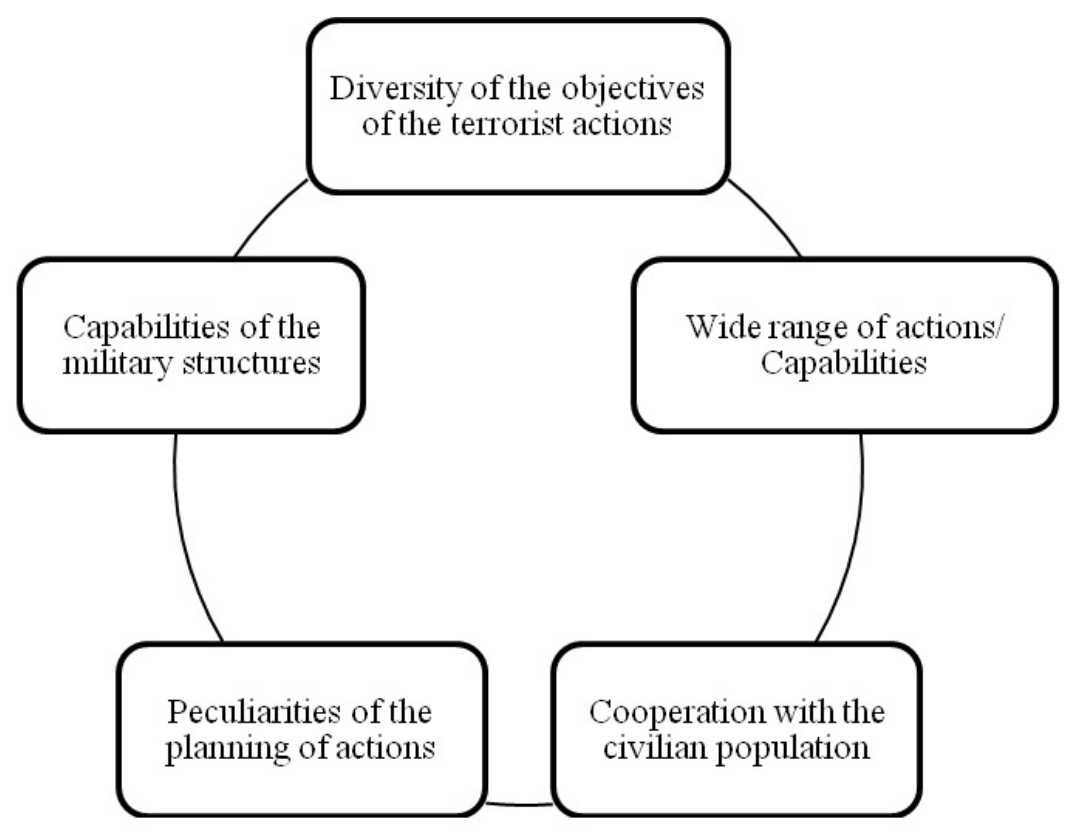

Figure 2: Comprehensive approach to the actions against terrorism

The comprehensive approach to combat terrorism requires a direct relation to the entire conflict and integration of the effects within the multinational joint operations to facilitate stabilization. Thus, it is beyond the military action, as it includes effects that involve the entire society, consisting in achieving and maintaining a stable and safe security environment. Regardless of their level (strategic, operational or tactical), the military multinational joint operations to counterterrorism have effects, to a lesser or greater extent, not only at a military but also a political, diplomatic, economic, psycho, social and humanitarian level, as the "operational environment consists of conditions, circumstances and influences affecting the context of capabilities and decision taking by commanders". (FM 3-0, p. 1-1).

\section{Conclusions}

The new paradigm of approaching the confrontation the terrorist entities 
determines a careful approach both from the perspective of the complex issues of the particularities of the operational environment and in terms of the training of the force structures. The actions of the terrorist entities generate a multitude of social and humanitarian problems due to the fact that many leave behind them human and social drama in the short, medium and long run. The present reality in Afghanistan, Syria, northern Iraq and from the areas controlled by ISIS shows this.One of them is the migration, due to the fact that in most cases, civilians are either evacuated, or self-evacuated, that turns into a mass of people trying to escape from the conflict to avoid being caught plunged into battles or to protect from reprisals and atrocities of the terrorist organizations.

The counterterrorism operations should be based on a prevailing attitude of conquest and maintain an ongoing initiative. This requires prevailing forms of action for the security forces of the host nation to be offensive type actions, while the defensive type operations should be the exception to the rule. The military forces must be concerned with ensuring efficient, continuous and permanent support with current information, to combine, depending on the course of actions, the forms and fighting skills appropriate to each of the stages.

An important role in the success of counterterrorism operations is the continuous contact between the military structures and the population in area of operations, to exchange information and create bridges between the military and the local population. The fight against terrorism involves the military forces, beyond the issues of legitimacy and legality, part of the commitment to the principles of democracy, human dignity and fundamental human rights.

[1] Balint Mario, http://mariobalint.blogspot.ro/2010/04/operatiuni-militare-externein.html, accesat la data de 14.02.2017.

[2] Field Manual, FM 3-24, Counterinsurgency, Departament of the Army, USA, 2006, chapter II.

[3] Col.drd. Constantin-ValentinBordei, Managementul ţintelor inconflictele moderne, Buletinul Universităţii Naţionale de Apărare „Carol I“, iunie 2015, pg.185, pe http://www.spodas.ro/revista/index.php/revista/article/viewFile/122/144, accesat la data de 26.03.2017.

[4] Centrul de studiistrategice, Terorismul. Dimensiune geopolitică și geostrategică.Războiul terorist.Războiul împotriva terorismului, EdituraAcademiei de Înalte Studii Militare, București, 2002.

[5] FM 3-0 Operations, Headquarters Department of the Army, Washington, 2009. 